\title{
Polyploidy, infraspecific cytotype variation, and speciation in Goldenrods: The cytogeography of Solidago subsect. Humiles (Asteraceae) in North America
}

\author{
Jess A. Peirson, ${ }^{1,2}$ Anton A. Reznicek ${ }^{2}$ \& John C. Semple ${ }^{3}$ \\ 1 Department of Ecology and Evolutionary Biology, The University of Michigan, Ann Arbor, Michigan 48109-1048, U.S.A. \\ 2 The University of Michigan Herbarium, 3600 Varsity Drive, Ann Arbor, Michigan 48108-2228, U.S.A. \\ 3 Department of Biology, University of Waterloo, Waterloo, Ontario N2L 3G1, Canada \\ Author for correspondence: Jess A. Peirson, peirsonj@umich.edu
}

\begin{abstract}
Polyploidy is an important evolutionary mechanism in plants, and in some genera (e.g., Solidago in Asteraceae) it is particularly widespread and is hypothesized to have played a major role in diversification. Goldenrods are notorious for their ploidy variation, with roughly $14 \%$ and $32 \%$ of recognized North American species being polyploid or including multiple cytotypes, respectively. We used traditional chromosome counts and flow cytometry to examine cytogeographic patterns, biogeographic and evolutionary hypotheses, and species boundaries in $S$. subsect. Humiles. Chromosome numbers and DNA ploidy determinations are reported for 337 individuals, including 148 new reports. Cytotypes show significant geographic structuring. Solidago simplex and $S$. spathulata were uniformly diploid $(2 n=18)$ in western North America, while cytogeographic patterns in eastern North America were regionally complex and included $2 n, 4 n$, and $6 n$ cytotypes. Cytotypes within $S$. simplex were ecogeographically segregated and mixed-ploidy populations were rare. Data from this study and additional biosystematic data indicate that cytotypes in S. simplex fulfill the requirements of multiple species concepts and should best be treated as distinct species. Polyploid cytotypes possibly formed recurrently, however, and evolution and species boundaries within polyploid S. simplex will require additional study. Results from this study and accumulated data from other studies suggest that biological species diversity in Solidago is considerably higher than currently recognized taxonomically.
\end{abstract}

Keywords cytogeography; flow cytometry; genome size; North America; polyploidy; Solidago

Supplementary Material Tables S1 and S2 are available in the free Electronic Supplement to the online version of this article (http://www.ingentaconnect.com/content/iapt/tax).

\section{INTRODUCTION}

Polyploidy has long been recognized as an important mechanism in plant evolution (Muntzing, 1936; Stebbins, 1971; Lewis, 1980). Results from early field and greenhouse studies demonstrated that polyploid plant species were often ecologically distinct from their diploid relatives and often occupied at least partially separate geographic ranges (Muntzing, 1936; Stebbins, 1942; Löve \& Löve, 1943; Clausen \& al., 1945; Haskell, 1951). Yet while our knowledge of the prevalence of polyploidy and the molecular genetics of polyploid function have greatly expanded over the last century (Ehrendorfer, 1980; Lewis, 1980; Soltis \& Soltis, 2000; Wendel, 2000; Soltis \& al., 2004; Parisod \& al., 2010), our understanding of the interplay of polyploidy and ecology and evolution remains considerably more limited (Soltis \& al., 2010). Despite these limitations, polyploidization is often regarded as a major driver of plant speciation and as probably the prime example of how sympatric speciation in plants can occur because it can confer instantaneous reproductive isolation (Coyne \& Orr, 2004; Rieseberg \& Willis, 2007; Soltis \& al., 2007).

Genomic data suggest that one or more whole-genome duplications occurred early in the evolution of the angiosperms (reviewed by Soltis \& al., 2009), and broad-scale surveys of ploidy data suggest that $30 \%-70 \%$ of flowering plants have some incidence of lineage-specific polyploidy in their histories (Stebbins, 1950; Grant, 1981; Masterson, 1994). The mostconservative models have estimated that between $2 \%-4 \%$ of speciation events in angiosperms have involved a change in ploidy (Otto \& Whitton, 2000; Coyne \& Orr, 2004). Wood \& al. (2009) suggest, however, that the actual incidence of polyploid speciation in flowering plants may be closer to $15 \%$, representing a four-fold increase over the earlier estimates. Wood \& al. also found that approximately $12 \%-13 \%$ of angiosperm species harbored some level of infraspecific ploidy variation (i.e., they comprised multiple ploidy races).

Soltis \& al. (2007) argued that while infraspecific ploidy variation in many groups has been ignored taxonomically, chromosomal races within many species actually fulfill the criteria of multiple species concepts. This widespread inclusion of multiple chromosomal races within broadly defined species has the potential to mask significant amounts of biological species diversity and to obscure our understanding of evolution and speciation in many groups (Soltis \& al., 2007). Concerns have also been raised that unrecognized infraspecific ploidy variation could pose major hurdles to the conservation of rare species and to ecological restoration efforts (Soltis \& al., 2007; Severns \& Liston, 2008). Soltis \& al. 
(2007) surmised that the reluctance of botanists to recognize infraspecific chromosomal races as distinct entities was due in part to a long botanical tradition of including multiple cytotypes in single species and to the practicality of relying on a largely phenetic species concept. This in turn raises questions for genera with substantial amounts of taxonomically unrecognized cytotypic variation. How is this cytotypic variation partitioned within species complexes? Are cytotypes ecologically, geographically, or morphologically distinct? Is it likely that polyploid cytotypes formed recurrently? Are cytotypes largely reproductively isolated? In what cases should infraspecific cytotypes be recognized as good biological species? How significantly have we underestimated the amount of biological species diversity in these groups?

In some groups in particular (e.g., genera like Packera Á. Löve \& D. Löve, Solidago L., and Symphyotrichum Nees in Asteraceae), polyploidy and infraspecific ploidy variation are abundant and appear to have played important roles in diversification and speciation (Brouillet \& al., 2006; Semple \& Cook, 2006; Trock, 2006; Semple \& Watanabe, 2009). Goldenrods (Solidago spp.) have long been notorious for their complex patterns of morphological and ploidy variation. The genus contains approximately 100 recognized species, with 77 of those native to the United States and Canada (Semple $\&$ Cook, 2006). Fourteen percent (11/77) of these species are strictly polyploid (i.e., they exist only at the tetraploid level or above). An additional 32\% (25/77) of North American species harbor some level of infraspecific cytotype variation. Cytological data extracted from Semple \& Cook (2006) indicate that chromosome numbers in the genus range from diploid $(2 n$ $=18)$ to $14 x(14 n=126)$. While these statistics indicate that approximately $46 \%$ of Solidago species show some direct incidence of polyploidy in their histories, cytotypes have typically been circumscribed at infraspecific rank or simply included in broadly defined taxa.

Solidago subsect. Humiles (Rydb.) Semple presents an interesting system in which to examine patterns of polyploidy and infraspecific cytotype variation. The subsection is composed of one widespread, taxonomically and cytologically complex species, Solidago simplex Kunth, and four narrowly endemic species. Solidago simplex was previously shown to be diploid throughout its range in western North America but to include diploid, tetraploid, and hexaploid populations in eastern North America. Ringius (1986) and Ringius \& Semple (1987) proposed that polyploid populations of $S$. simplex (treated as $S$. glutinosa Nutt. at the time) in eastern North America evolved from a single migration of diploid $S$. simplex from western North America and subsequent polyploidization. The recent description of two closely related species, the tetraploid $S$. arenicola Keener \& Kral (2003) and diploid S. kralii Semple (2003), and rediscovery of $S$. plumosa Small (ploidy unknown, thought to have been extinct, A. Weakley pers. comm.) in the southeastern United States, however, have raised questions concerning cytogeographic patterns within the complex and the previous hypothesis of a single origin of polyploidy in $S$. subsect. Humiles. In addition, our inclusion of previously unstudied populations in the glaciated Great Lakes region showed that the cytogeography of $S$. simplex within the region had not been adequately characterized.

This study uses chromosome counts and flow cytometry data in Solidago subsect. Humiles to address the following main questions: (1) With our increased taxon and population sampling, what are the distributions of cytotypes in Solidago subsect. Humiles across its North American range, and how are those cytotype distributions different from the ones presented in Ringius (1986) and Ringius \& Semple (1987)? (2) What does our expanded knowledge of cytogeographic patterns tell us about the biogeographic and evolutionary history of Solidago subsect. Humiles (e.g., the Holocene biogeography of $S$. simplex and single vs. recurrent origin of polyploidy)? (3) Using a framework similar to that described by Soltis \& al. (2007), what do cytogeographic patterns and additional biosystematic data tell us about potential species boundaries between cytotypes of $S$. simplex, and how does this compare to patterns found in other Solidago species complexes with similar ploidy variation.

\section{MATERIALS AND METHODS}

Study group. - Solidago subsect. Humiles is composed of five species: $S$. arenicola, $S$. kralii, S. plumosa, S. spathulata DC., and S. simplex (following Semple \& Cook, 2006). The goldenrods in $S$. subsect. Humiles have resinous glands on the foliage and involucral bracts that cause all members of the group to be glutinous. In addition, all species in the subsection have virgate to paniculiform arrays with non-secund capitula (Semple \& Cook, 2006).

Solidago subsect. Humiles is endemic to North America and transcontinental in distribution. The broadly circumscribed Solidago simplex is widespread and transcontinental in distribution but absent from the center of the continent. Other species are much more restricted. Solidago arenicola, S. kralii, and $S$. plumosa are narrowly distributed endemics in the southeastern United States (Fig. 1). Solidago arenicola is restricted to rocky or sandy riverbanks and floodplains in the Cumberland Plateau region of northern Alabama and Tennessee. Solidago kralii is confined to sand hills along the Coastal Plain fall line in a small area of Georgia and South Carolina. Solidago plumosa is known from a single population on mafic rocks along the Yadkin River in Stanley Co., North Carolina. Solidago spathulata inhabits sand dunes along the Pacific coast from central California to northern Oregon (Fig. 1).

Ringius (1986) divided Solidago simplex into diploid S. simplex subsp. simplex $(2 n=18)$ and polyploid $S$. simplex subsp. randii $(4 n=36,6 n=54)$. Diploid subsp. simplex is widespread yet patchily distributed in montane and alpine habitats throughout the western cordillera from Alaska to Mexico (Fig. 1; var. simplex and var. nana (A. Gray) Ringius). Disjunct, eastern diploid populations in the northern Great Lakes region and Gaspé, Quebec have also been placed in subsp. simplex (Fig. 1; var. simplex and var. chlorolepis (Fern.) Ringius, respectively). Polyploid subsp. randii is restricted to the Great Lakes region and Appalachian Mountains in eastern North America (Fig. 1), and four varieties are currently recognized in the subspecies. 
Solidago simplex subsp. randii var. racemosa (Greene) Ringius inhabits rocky riverbanks throughout the Appalachian Mountains, from West Virginia to New Brunswick, while $S$. simplex subsp. randii var. monticola (Porter) Ringius is confined to barrens and serpentine soils in New England and southern Quebec. Solidago simplex subsp. randii var. ontarioensis (Ringius) Ringius and S. simplex subsp. randii var. gillmanii (A. Gray) Ringius are endemic to the Great Lakes region, inhabiting rocky shores from the Bruce Peninsula, Ontario to southern and eastern Lake Superior and active dune systems along the shores of lakes Huron and Michigan, respectively.
Field sampling. - Our sampling scheme filled in gaps in coverage (taxonomic and geographic) in previously underrepresented regions (e.g., the southeastern United States) and greatly increased coverage in regions with potentially complex cytogeographic patterns (e.g., the Great Lakes region). We sampled taxa from across their ranges in the Great Lakes region and the southeastern United States, with several additions from eastern and western North America (Table 1). At each site, we harvested rhizome cuttings from 1-9 widely spaced individuals (clones spaced $>3 \mathrm{~m}$ apart). We then transplanted those cuttings to Matthaei Botanical Gardens at the University of Michigan

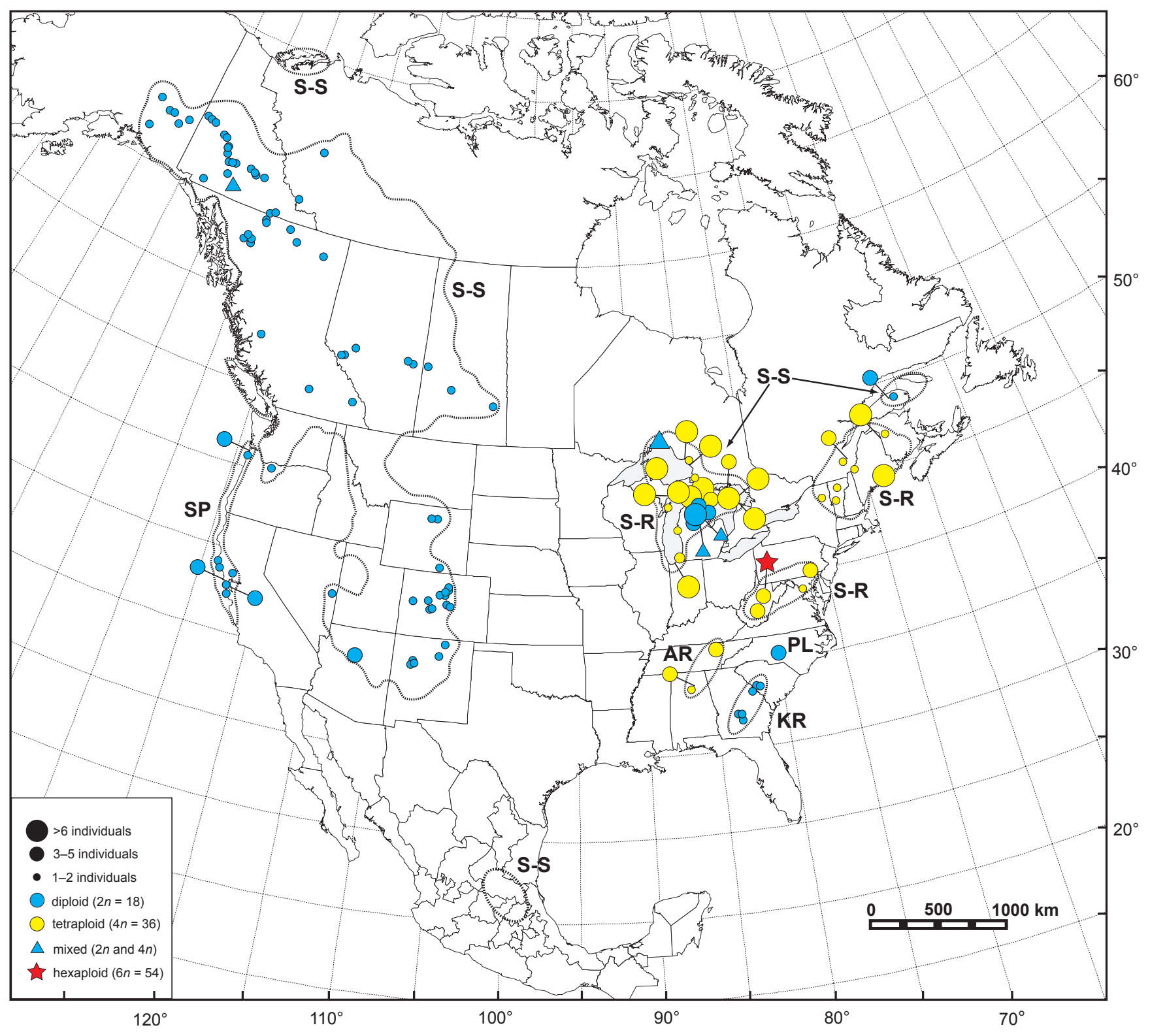

Fig. 1. Distribution of cytotypes within Solidago simplex and the other species of Solidago subsect. Humiles in North America based on data from this study and from literature reports. Generalized distributions of each species are indicated by dashed lines except for $S$. plumosa, which is indicated by a single point. Taxa are labeled as follows: AR, S. arenicola; KR, S. kralii; PL, S. plumosa; S-R, S. simplex subsp. randii; S-S, S. simplex var. simplex; SP, S. spathulata. Symbols are scaled for sample sizes at each population. Mixed-ploidy population samples consisted of four to six diploid individuals with a single tetraploid individual (see text). 
Table 1. Locality information for 40 populations of Solidago subsect. Humiles sampled in this study. Nomenclature follows Semple \& Cook (2006). Countries are designated as follows: Can, Canada; U.S.A., United States. Collector abbreviations are as follows: JP, J. Peirson; $S$, J. Semple; $S \& S$, J. Semple \& B. Semple; Voss, E.G. Voss; Hr\&St, Hrusa \& G.L. Stebbins. JP and Voss vouchers are deposited at MICH; $S, S \& S$, and Hr\&St vouchers are deposited at WAT. The majority of ploidy determinations $(2 n, 4 n, 6 n)$ were inferred from flow cytometry analysis. Direct chromosome counts are indicated by an asterisk $(*)$.

\begin{tabular}{|c|c|c|c|c|c|c|c|c|c|}
\hline & \multirow[b]{2}{*}{ Country } & \multirow[b]{2}{*}{ State } & \multirow[b]{2}{*}{ County } & \multirow[b]{2}{*}{ Lat. } & \multirow[b]{2}{*}{ Long. } & \multicolumn{3}{|c|}{ No. individuals } & \multirow[b]{2}{*}{ Voucher(s) } \\
\hline & & & & & & $2 n$ & $4 n$ & $6 n$ & \\
\hline \multicolumn{10}{|l|}{ Solidago arenicola } \\
\hline Locust Creek at Rte 231 & U.S.A. & Alabama & Blount & 34.02 & -86.57 & - & 2 & - & $J P 608$ \\
\hline Swann Bridge & U.S.A. & Alabama & Blount & 34.00 & -86.60 & - & $1+1^{*}$ & - & JP 609, S\&S 11196 \\
\hline Lily Bridge & U.S.A. & Tennessee & Morgan & 36.10 & -84.72 & - & 4 & - & $J P 610$ \\
\hline
\end{tabular}

\section{Solidago kralii}

Vaucluse

I-20 north of Graniteville

Bowens Mill 1

Bowens Mill 2

Hartford

\section{Solidago plumosa}

Yadkin River
U.S.A. South Carolina

U.S.A. South Carolina Aiken

U.S.A. Georgia

U.S.A. Georgia

U.S.A. Georgia

U.S.A. North Carolina Stanley

$\begin{array}{llllll}33.61 & -81.82 & 1 & - & - & J P 605 \\ 33.62 & -81.83 & 1^{*} & - & - & S \& S 11218 \\ 31.84 & -83.21 & 1^{*} & - & - & S \& S 11212 \\ 31.84 & -83.21 & 1^{*} & - & - & S \& S 11216-B \\ 32.25 & -83.40 & 1^{*} & - & - & S \& S 11208\end{array}$

$\begin{array}{lllllll}35.41 & -80.09 & 3 & - & - & J P & 604\end{array}$

Solidago simplex subsp. randii var. gillmanii

\begin{tabular}{|c|c|c|c|c|c|c|c|c|c|}
\hline West of Detour Village & U.S.A. & Michigan & Chippewa & 45.97 & -84.06 & - & 7 & - & Voss 168 \\
\hline West of Manistique & U.S.A. & Michigan & Schoolcraft & 45.91 & -86.32 & - & 8 & - & $J P 590$ \\
\hline Silver Lake State Park & U.S.A. & Michigan & Oceana & 43.65 & -86.54 & - & 2 & - & $J P 595$ \\
\hline Wilderness State Park at Sturgeon Bay & U.S.A. & Michigan & Emmet & 45.71 & -84.95 & - & 7 & - & $J P 531$ \\
\hline Thompson's Harbor State Park & U.S.A. & Michigan & Presque Isle & 45.35 & -83.57 & - & 5 & - & $J P 789$ \\
\hline Warren Dunes State Park & U.S.A. & Michigan & Berrien & 41.91 & -86.60 & - & 4 & - & $J P 517$ \\
\hline \multicolumn{10}{|c|}{ Solidago simplex subsp. randii var. monticola } \\
\hline Falls of Lana & U.S.A. & Vermont & Addison & 43.90 & -73.06 & - & 2 & - & $J P 581$ \\
\hline \multicolumn{10}{|c|}{ Solidago simplex subsp. randii var. ontarioensis } \\
\hline West of Sault St. Marie, Gros Cap & Can & Ontario & Algoma & 46.53 & -84.59 & - & $1 *$ & - & $S 11086$ \\
\hline Tobermory, Big Tub Lighthouse & Can & Ontario & Bruce & 45.26 & -81.67 & - & 5 & - & $J P 475$ \\
\hline Georgian Bay & Can & Ontario & Bruce & 45.25 & -81.52 & - & 4 & - & $J P 560$ \\
\hline Fort Wilkins State Park & U.S.A. & Michigan & Keweenaw & 47.47 & -87.86 & - & 5 & - & $J P 625$ \\
\hline Tobermory, Elgin Street & Can & Ontario & Bruce & 45.26 & -81.64 & - & 6 & - & $J P 562$ \\
\hline Government Dock & Can & Ontario & Algoma & 47.94 & -84.85 & - & 6 & - & $J P 557$ \\
\hline South of Tobermory, Hay Bay Road & Can & Ontario & Bruce & 45.24 & -81.68 & - & 6 & - & $J P 563$ \\
\hline Sandy Beach & Can & Ontario & Algoma & 47.96 & -84.86 & - & 1 & - & $J P 555$ \\
\hline Seul Choix Point & U.S.A. & Michigan & Schoolcraft & 45.92 & -85.91 & - & 9 & - & $J P 467$ \\
\hline
\end{tabular}

Solidago simplex subsp. randii var. racemosa

\begin{tabular}{|c|c|c|c|c|c|c|c|}
\hline Middle Fork River at Audra & U.S.A. & West Virginia & Barbour & 39.04 & -80.07 & - & $J P 598$ \\
\hline Carnifex Ferry & U.S.A. & West Virginia & Nicholas & 38.21 & -80.94 & - & $J P 603$ \\
\hline
\end{tabular}


Table 1. Continued.

\begin{tabular}{lllllllllll}
\hline & & & & & \multicolumn{3}{c}{ No. individuals } \\
\cline { 5 - 8 } & Country & State & County & Lat. & Long. & $2 n$ & $4 n$ & $6 n$ & Voucher(s) \\
\hline Holton Dam & U.S.A. & Pennsylvania & York & 39.81 & -76.33 & - & 4 & - & $J P 585$ & \\
Valley Falls & U.S.A. & West Virginia & Marion & 39.39 & -80.09 & - & - & 5 & $J P 597$ & $J 7$
\end{tabular}

Solidago simplex subsp. simplex var. simplex

\begin{tabular}{|c|c|c|c|c|c|c|c|c|c|}
\hline Rte 612 and Deward Road & U.S.A. & Michigan & Kalkaska & 44.77 & -84.85 & 3 & - & - & $J P 464$ \\
\hline I-75 south of Gaylord & U.S.A. & Michigan & Otsego & 44.97 & -84.67 & 4 & - & - & $J P 647$ \\
\hline Fletcher Road & U.S.A. & Michigan & Kalkaska & 44.57 & -85.06 & 1 & - & - & $J P 541$ \\
\hline Big Creek Road & U.S.A. & Michigan & Oscoda & 44.67 & -84.28 & 3 & - & - & $J P 542$ \\
\hline North of St. Helena & U.S.A. & Michigan & Roscommon & 44.40 & -84.41 & 4 & 1 & - & $J P 463$ \\
\hline Rte 612 and I-75 & U.S.A. & Michigan & Crawford & 44.78 & -84.72 & 7 & - & - & $J P 538$ \\
\hline Staley Lake Road & U.S.A. & Michigan & Crawford & 44.65 & -84.64 & 4 & 1 & - & $J P 535$ \\
\hline Nahanni National Park Reserve & Can & NW Territories & - & 61.42 & -126.84 & $1 *$ & - & - & $S 11156$ \\
\hline Terrace Bay & Can & Ontario & Thunder Bay & 48.77 & -87.11 & 5 & 1 & - & $J P 550$ \\
\hline
\end{tabular}

Solidago spathulata

Gearhart/Seaside

U.S.A. Oregon Clatsop

$\begin{array}{lllllll}46.02 & -123.93 & 2 & - & - & J P & 636\end{array}$

Cavedale Rd east of Hwy-12

U.S.A. California

Sonoma

$\begin{array}{llllll}38.38 & -122.46 & 1^{*} & - & - & H r \& S t \\ 11428\end{array}$

or to the University of Waterloo North Campus Greenhouses. For each population, we deposited a single population voucher in MICH or WAT. We potted rhizome/rootstock cuttings in standard potting soil and watered them weekly.

Chromosome number and DNA ploidy determination. - We made meiotic counts from pollen mother cells dissected from field-prepared buds fixed in acetic ethanol $(3: 1 /$ EtOH: glacial acetic acid) and mitotic counts from root tip preparations following protocols outlined in Semple \& Cook (2004). We prepared permanent slides for some samples following protocols in Semple \& al. (1981).

We determined DNA ploidy (sensu Hiddeman \& al., 1984) using flow cytometry after calibrating the relative DNA content (from flow cytometry) with previously determined chromosome numbers from a subset of populations in the study. We used at least one calibration/standardization for each recovered DNA ploidy level $(2 x, 4 x, 6 x)$. Other studies have used similar methodologies for a number of plant species, including two other species of Solidago (Halverson \& al., 2008; Schlaepfer $\&$ al., 2008a).

We harvested fresh Solidago leaf material from greenhouse-grown plants and stored it in cool conditions for up to one week. For each sample, we chopped approximately one half of a young leaf in $0.8 \mathrm{ml}$ ice-cold LB01 buffer (Dolezel $\&$ al., 1989) with $50 \mu \mathrm{g} / \mathrm{ml}$ propidium iodide and added $50 \mu \mathrm{g} /$ $\mathrm{ml}$ RNAse. We used an approximately equal amount of fresh leaf from Glycine $\max$ (L.) Merr. 'Polanka' as an internal DNA content standard (2.5 pg/2c; cited in Dolezel \& al., 1994, 2007). After chopping, we filtered each sample through a $30 \mu \mathrm{m}$ filter into a microcentrifuge tube. We centrifuged each sample and removed the supernatant. We then resuspended the pellet in 50 $\mu \mathrm{g} / \mathrm{ml}$ propidium iodide and incubated it at room temperature for 20-45 minutes. We ran samples on a BD FACSCalibur flow cytometer in the Department of Integrative Biology at the University of Guelph.

We analyzed most samples (128/140) using Modfit v.3.0 software (Verity Software) to estimate peak means, coefficients of variation (CV), and nuclei number. For twelve samples in which the Solidago peak was very close to the Glycine max peak, we used CellQuest Pro v.4.0 software, manually gating peaks. We calculated DNA content as:

$$
\text { DNA Content }=2.5 \times \frac{\text { Solidago mean }}{\text { Glycine max mean }}
$$

where 2.5 equals the standardized mean genome size of Glycine $\max$ (in $\mathrm{pg} / 2 \mathrm{c}$ ) and the other mean values represent the experimentally determined values for each sample.

Literature review and mapping. - We compiled published chromosome counts through literature searches and through cross-referencing with Ringius \& Semple (1987). We listed population and cytovoucher data for literature reports accepted in this study in Table S1 (Electronic Supplement). At least one of the authors examined cytovouchers for nearly all literature reports to confirm species determinations. We georeferenced populations and pooled the literature counts with data from this study to create cytogeographic maps representing all taxa in Solidago subsect. Humiles. We considered reports from the same locality (populations $<1 \mathrm{~km}$ apart when georeferenced) as intrapopulation samples for mapping purposes. 


\section{RESULTS}

Chromosome counts, flow cytometry, and literature reports. - Chromosome numbers and DNA ploidy determinations are reported for five species and 337 individuals, including 148 new reports (Table 2). This compares to two species and ca. 130 reports in Ringius \& Semple (1987). Of the 148 new reports, 140 were DNA ploidy determinations from flow cytometry and 8 were direct counts (Tables $1-2$ ). Flow cytometry recovered three non-overlapping DNA ploidy groups that correspond to $2 x, 4 x$, and $6 x$ counts (Table 3; Fig. 2). These data were consistent with literature reports and indicated that only three ploidy levels have been found in $S$. subsect. Humiles: diploid $(2 n=18)$, tetraploid $(4 n=36)$, and hexaploid $(6 n=54)$. No odd-ploidy individuals (e.g., triploid with $3 n=27$ or pentaploid with $5 n=45$ ) have been detected in $S$. subsect. Humiles.

Cytogeographic patterns. - Cytotypes within $S$. subsect. Humiles show significant geographic and taxonomic structuring (Figs. 1, 3). All counts from western North America were diploid except for one tetraploid count of $S$. simplex var. simplex from the Yukon Territory, Canada (see below). Patterns in eastern North America were more complex at a regional level and included diploid, tetraploid, and hexaploid populations. In general, however, cytotypes in eastern North America had regionally allopatric distributions. A single West Virginia population of $S$. simplex var. racemosa was found to be hexaploid. Our diploid DNA ploidy determination represents the first report for S. plumosa Small and is consistent with an unpublished direct count (G. Nesom, pers. comm. to J. Semple).

Although multiple ploidy levels were found in eastern North America, almost no within-population variation was observed. Three mixed-ploidy populations were discovered in this study (mean number of intrapopulation samples $=5.33$, minimum $=5$, maximum $=6$ ). In each case, a single, cryptic tetraploid individual was recovered from an otherwise diploid population in the northern Great Lakes region. Because the number of individuals sampled per population was small (5-6 individuals in the mixed-ploidy populations), our

Table 2. Summary of chromosome counts and DNA ploidy determinations for Solidago subsect. Humiles from this study and from literature reports. Rare exceptions to the general patterns within S. simplex are enclosed in parentheses. Hexaploid determinations from Valley Falls, West Virginia are indicated by an asterisk (*). Detailed information on study sites and literature reports is presented in Tables 1 and S1, respectively.

\begin{tabular}{|c|c|c|c|c|c|}
\hline Taxon & $\begin{array}{l}\text { Somatic } \\
\text { chromosome no. }\end{array}$ & DNA ploidy & $\begin{array}{l}\text { No. of dets. } \\
\text { from literature }\end{array}$ & $\begin{array}{l}\text { No. of dets. } \\
\text { this study }\end{array}$ & $\begin{array}{l}\text { Total no. } \\
\text { of counts }\end{array}$ \\
\hline S. arenicola & $2 n=36$ & $4 n$ & 1 & 8 & 9 \\
\hline S. kralii & $2 n=18$ & $2 n$ & 2 & 5 & 7 \\
\hline S. plumosa & $2 n=18$ & $2 n$ & - & 3 & 3 \\
\hline S. simplex & $2 n=18,36,54$ & $2 n, 4 n, 6 n$ & 174 & 129 & 303 \\
\hline subsp. randii & $2 n=36(54)$ & $4 n(6 n)$ & $74(6)$ & $89(5)$ & $163(11)$ \\
\hline var. gillmanii & $2 n=36$ & $4 n$ & 15 & 33 & 48 \\
\hline var. monticola & $2 n=36$ & $4 n$ & 15 & 2 & 17 \\
\hline var. ontarioensis & $2 n=36$ & $4 n$ & 23 & 43 & 66 \\
\hline var. racemosa & $2 n=36(54 *)$ & $4 n\left(6 n^{*}\right)$ & $21\left(6^{*}\right)$ & $11\left(5^{*}\right)$ & $32\left(11^{*}\right)$ \\
\hline subsp. simplex & $2 n=18(36)$ & $2 n(4 n)$ & $93(1)$ & $32(3)$ & $125(4)$ \\
\hline var. chlorolepis & $2 n=18$ & - & 7 & - & 7 \\
\hline var. nana & $2 n=18$ & - & 1 & - & 1 \\
\hline var. simplex & $2 n=18(36)$ & $2 n(4 n)$ & $85(1)$ & $32(3)$ & $117(4)$ \\
\hline S. spathulata & $2 n=18$ & $2 n$ & 12 & 3 & 15 \\
\hline Totals & & & 189 & 148 & 337 \\
\hline
\end{tabular}

Table 3. Sample frequencies and relative DNA content as determined by flow cytometry analysis of fresh leaf tissue from species in Solidago subsect. Humiles. Populations with both $2 n$ and $4 n$ cytotypes were counted twice.

\begin{tabular}{llllll}
\hline & & & \multicolumn{3}{c}{ Relative DNA content } \\
\cline { 4 - 6 } Ploidy level & No. populations & No. individuals & Mean $( \pm$ SD $)$ & Min. & Max. \\
\hline Diploid & 11 & 37 & $2.30(0.06)$ & 2.21 & 2.50 \\
Tetraploid & 24 & 98 & $4.36(0.11)$ & 4.07 & 4.58 \\
Hexaploid & 1 & 5 & $6.08(0.08)$ & 5.96 & 6.17 \\
\hline
\end{tabular}


ability to detect rare cytotypes at the population level was also low. Beaudry (1969) reported the only other mixed-ploidy counts for subsect. Humiles from Lac Laberge, Yukon Territory, Canada. His single tetraploid and four diploid counts, however, were all from seedlings germinated from a single maternal individual.

Rejected reports. - Sixteen literature reports were rejected due to misidentifications (Table S2 in the Electronic Supplement).

\section{口 DISCUSSION}

Cytogeography of Solidago subsect. Humiles. - This study confirmed many of the broad-scale patterns found by previous cytogeographic work on S. simplex and S. spathulata (Ringius \& Semple, 1987), but our increased taxon and population coverage provided greater resolution and revealed additional patterns not previously documented (especially in the Great Lakes region and the southeastern United States).
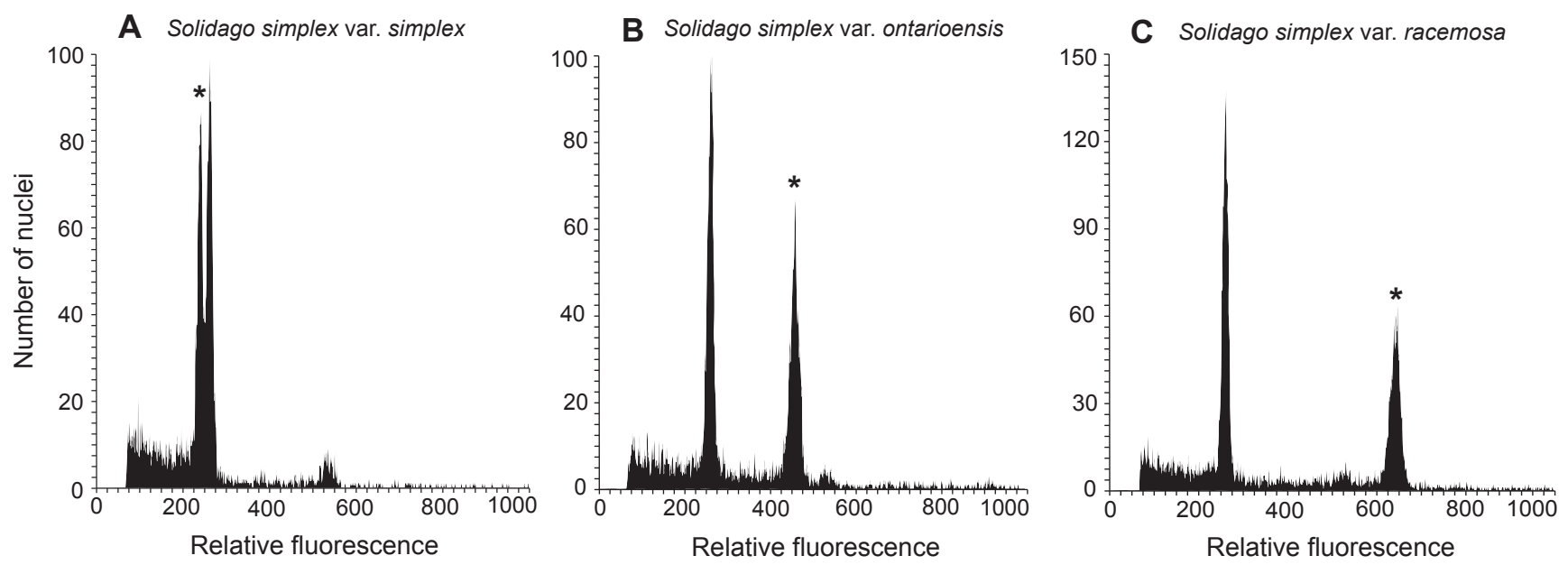

Fig. 2. Fluorescence histograms of stained nuclei isolated during flow cytometry analyses of fresh tissue of Solidago simplex and the internal standard (Glycine max 'Polanka'). The Solidago peak is indicated with an asterisk. A, diploid S. simplex var. simplex from Oscoda County, Michigan; B, tetraploid S. simplex var. ontarioensis from Tobermory, Ontario; C, hexaploid S. simplex var. racemosa from Valley Falls, West Virginia.

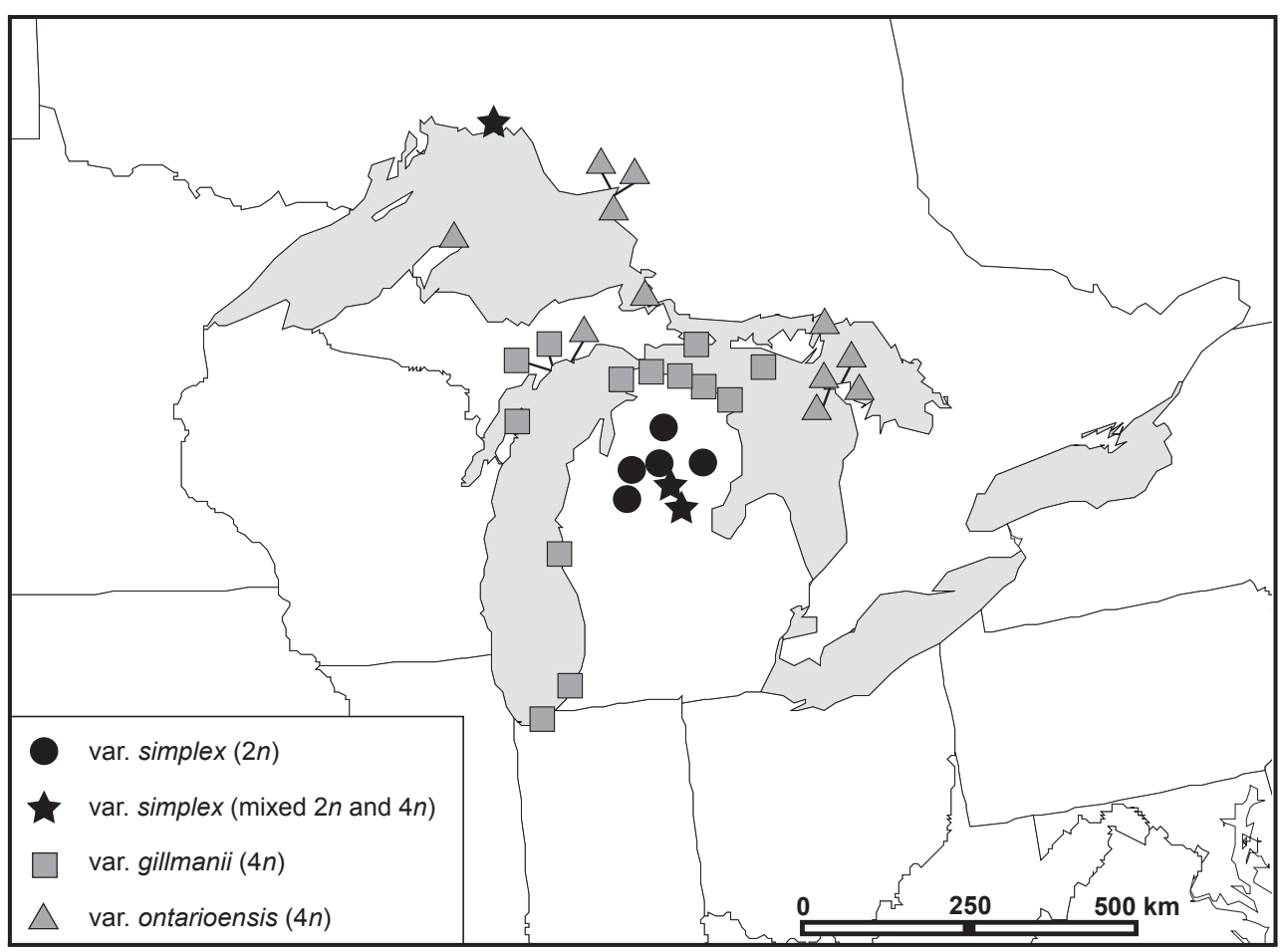

Fig. 3. Distribution of cytotypes within Solidago simplex in the North American Great Lakes region: diploid $S$. simplex var. simplex (black circles); mixed diploid and tetraploid S. simplex var. simplex (black stars); tetraploid $S$. simplex var. gillmanii (shaded squares); tetraploid $S$. simplex var. ontarioensis (shaded triangles). Mixed ploidy S. simplex var. simplex population samples consisted of five or six diploid individuals with a single, cryptic tetraploid individual (see text). 
Patterns in western North America remain unchanged from earlier studies; the subsection is known almost entirely at the diploid level throughout its range from Alaska and northern Canada south through the Rocky Mountains and along the Pacific coast. Disjunct populations in the mountains of northern Mexico are also presumed to be diploid but have not yet been sampled for cytogeographic work. Cytogeographic patterns in eastern North America from Maryland north and east through New England, Quebec, and New Brunswick remain essentially unchanged from earlier studies. Solidago simplex var. monticola and S. simplex var. racemosa are tetraploid throughout their scattered, disjunct ranges in this region. A recent literature report confirmed the highly restricted distribution of diploid S. simplex var. chlorolepis on serpentine outcrops in Gaspé, Quebec (Gervais \& al., 1999). Patterns in the Great Lakes region, the southern Appalachians, and the southeastern United States, however, are considerably more complex than previously shown.

In the Great Lakes region, cytogeographic patterns in $\mathrm{S}$. simplex var. gillmanii and S. simplex var. ontarioensis broadly conformed to patterns found in previous studies (Fig. 3). Tetraploid $S$. simplex var. gillmanii is restricted to active coastal sand dunes along the shores of Lake Michigan and Lake Huron (the other varieties of $S$. simplex do not occur in this habitat type). Tetraploid S. simplex var. ontarioensis is restricted to limestone/ dolomite shorelines and outcrops along the Niagara Escarpment in Ontario and Michigan and to granite/basalt outcrops along the eastern shore of Lake Superior and the Keweenaw Peninsula. Observation of plants in the common garden suggests that S. simplex var. ontarioensis is composed of two phenotypically distinct sets of populations (Peirson, 2010). Larger-statured plants are restricted to dolomite shores along the boundary of the Niagara Escarpment, while smaller-statured plants occur predominantly on the granite/basalt outcrops around Lake Superior. This phenotypic differentiation in S. simplex var. ontarioensis raises the possibility that there are two lineages of tetraploid rock outcrop plants in the Great Lakes region.

Solidago simplex var. simplex is composed of two allopatric, ecologically distinct sets of populations in the Great Lakes region, a distribution that is considerably different from what earlier studies proposed (Fig. 3). While we confirmed previous reports of diploid S. simplex var. simplex along the northern shore of Lake Superior (east to Terrace Bay, Ontario), our results indicated that it does not extend southeastward to the eastern shore of Lake Superior or to the Bruce Peninsula of Lake Huron. Ringius \& Semple (1987) concluded that diploid and tetraploid S. simplex occurred sympatrically in the Great Lakes region because diploid counts from the eastern shore of Lake Superior and from Lake Huron had previously been assigned to S. simplex var. simplex (Morton, 1981; Semple \& al., 1981; Ringius \& Semple, 1987). Examination of cytovouchers from these studies and plants transplanted to the Matthaei Botanical Gardens for this study, however, indicated that these diploid, rock outcrop plants are not $S$. simplex. They appear most similar to the sand dune endemic S. hispida var. huronenis Semple.

In addition to the Lake Superior shoreline populations, we documented disjunct inland occurrences of diploid S. simplex var. simplex in northern Lower Michigan. These diploid populations were restricted to xeric, sandy soils in jack pine (Pinus banksiana Lamb.) barrens. Zimmerman (1956) first noted the occurrence of these inland populations, but neither Ringius (1986) nor Ringius \& Semple (1987) included them in their biosystematic and cytogeographic studies. Voss (1996) surmised that these plants might be allied with western North American S. simplex var. simplex based on their rather numerous, small capitula (ca. $4-5 \mathrm{~mm}$ ) but was unsure of their ploidy. Morphologically, plants in these populations are strikingly similar to diploid S. simplex populations from Wyoming, Montana, and southwestern Canada. In Michigan, these goldenrods occur in pine barren communities with several other disjunct western North American species (e.g., Agoseris glauca (Pursh) D. Dietr. and Festuca altaica Trin.), which are also absent from similar pine barren communities in Michigan's Upper Peninsula and northern Wisconsin (Johnston, 1958; Mustard, 1982).

Previous cytogeographic studies did not examine populations of Solidago simplex from the southeastern United States (south and west of Maryland) or include any of the currently recognized southeastern endemic species. Our inclusion of $S$. arenicola, S. kralii, S. plumosa, and southern populations of S. simplex var. racemosa in West Virginia greatly increased our understanding of cytogeographic patterns in the region. Both S. kralii and S. plumosa are diploid throughout their highly restricted ranges and represent the only diploid members of $S$. subsect. Humiles in the southeastern United States. Solidago arenicola is tetraploid throughout its scattered, disjunct range along river systems of the Cumberland Plateau in Alabama and Tennessee. The Tennessee plants were only tentatively included in $S$. arenicola by Semple \& Cook (2006), but their wide-spatulate rosette leaves, few-headed arrays with large capitula (ca. 8-12 mm), and occurrence in deep sandy alluvium along river floodplains clearly unite them with S. arenicola from northern Alabama.

Prior to this study, the ploidy of disjunct, southern populations of S. simplex var. racemosa in the Appalachian Mountains of West Virginia was unclear. A set of hexaploid counts from Valley Falls, West Virginia in the 1950s (Beaudry, 1963) raised the possibility that robust, large-headed plants along the New and Gauley Rivers and their tributaries represented a distinct group of hexaploid populations. We examined three populations of S. simplex var. racemosa from West Virginia, including the Valley Falls population. All chromosome counts and flow cytometry determinations from Valley Falls were hexaploid. Ploidy determinations from the other West Virginia populations indicated that plants in those populations were tetraploid. These results indicate that the variety is likely tetraploid throughout most of the Appalachian Mountains; the Valley Falls site remains the only location where hexaploid individuals of $S$. subsect. Humiles have been recorded.

Biogeography and evolution in Solidago simplex. - The complex cytogeographic patterns revealed by this study and much recent work on the evolution of polyploid plant species suggest that the original biogeographic and evolutionary hypotheses proposed by Ringius (1986) and Ringius \& Semple (1987) for $S$. simplex were likely too simple. Their cytogeographic work 
identified disjunct occurrences of diploid S. simplex subsp. simplex at the northern extreme of the distribution in eastern North America. They hypothesized that these rare diploids represented either relicts from a previously more widespread distribution (e.g., var. chlorolepis in Gaspé, Quebec) or postglacial migrants from an Alaskan-Beringian refugium (e.g., var. simplex along the northern shore of Lake Superior). Our increased sampling in the Great Lakes region revealed a third, more southerly, disjunct group of diploid populations. Do these populations represent an additional migration of diploid $S$. simplex from western North America? Or do all three disjunct occurrences of diploid S. simplex represent remnants of a previously more widespread distribution in northeastern North America? The occurrence of diploids throughout glaciated western Canada and at the northern extreme of the distribution in eastern North America runs counter to the long-standing hypothesis that polyploid plants were better colonizers than diploids following the last glaciation (Brochmann \& al., 2004; Ehrendorfer, 1980).

In addition to diploids at the northern extreme of the distribution, we also documented diploids at the southern extreme of the distribution in the southeastern United States (S. kralii and S. plumosa). This is significant because diploid S. plumosa is ecologically and morphologically similar to populations of tetraploid S. simplex var. racemosa from the southern Appalachians. Semple \& Cook (2006) noted this similarity and suggested that $S$. plumosa might be conspecific with S. simplex. This raises the possibility that $S$. plumosa (or a closely related diploid ancestor) was involved in the origin of $S$. simplex var. racemosa in the southeastern United States. Greene (1898) segregated these southern populations as the specifically distinct $S$. racemosa Greene. Thus the presence of ecologically and morphologically distinct endemic species in the southeastern United States (especially the diploid S. plumosa) suggests a more complicated evolutionary history within $S$. subsect. Humiles than previously proposed.

While Ringius \& Semple (1987) formally proposed that tetraploid Solidago simplex subsp. randii was a monophyletic lineage that had a single origin from diploid S. simplex, Ringius (1986) cited the great amount of morphological variation in the polyploid subspecies as evidence that its origins may have been polyphyletic. Phylogeographic data suggests that polyploids formed multiple times and do not represent an ancient monophyletic lineage (Peirson, in prep.). Polyploid individuals harbored 24 distinct chloroplast haplotypes that did not form a single clade; eight haplotypes were shared with diploids while 16 were found in polyploids only. A single origin of polyploidy would result in one ancestral chloroplast haplotype. Either polyploids evolved multiple times, or extensive gene flow and chloroplast capture from other polyploid Solidago species have resulted in a complex pattern of haplotype diversity. The plausibility of the recurrent origin of polyploids in S. simplex is further supported by the rare occurrence of cryptic tetraploids in otherwise diploid populations. While these data do not indicate extensive recurrent polyploidy, they do show that polyploid formation and potential speciation in S. simplex can potentially occur on contemporary ecological timescales. Interestingly, the three mixed-ploidy populations discovered during this study were in the recently glaciated Great Lakes region. This raises the potential that the endemic polyploid varieties of S. simplex in the Great Lakes region had postglacial origins from diploids in the region.

The probable recurrent evolution of higher ploidy lineages in S. simplex is consistent with conclusions from other goldenrod species. Schlaepfer \& al. (2008b) determined that multiple polyploidization events were significantly more likely than a single origin of tetraploids in S. gigantea. They inferred as many as seven independent origins in eastern North America. Similarly, Halverson \& al. (2008) concluded that the evolution of polyploidy in S. altissima was complex, and they rejected the hypothesis that polyploid cytotypes had a single, ancient origin. Together, these results from Solidago are consistent with numerous molecular phylogenetic studies that have demonstrated that the recurrent formation of polyploid lineages is the norm in many groups (Segraves \& al., 1999; Soltis \& Soltis, 1999; Soltis \& al., 2004; Rebernig \& al., 2010; Symonds \& al., 2010; Artyukova \& al., 2011).

Cytotype variation and species boundaries. - Cytogeographic patterns in Solidago simplex reveal a widely distributed species composed of two cytologically distinct, essentially allopatric subspecies that are each in turn composed of several ecologically, geographically, and morphologically separable taxa. At some point, the packaging of this vast amount of biological diversity into a single species raises the question: How many biological species are actually represented by $S$. simplex? Below we examine the more focused question of whether the cytotypes within $S$. simplex (i.e., diploid subsp. simplex and polyploid subsp. randii) actually represent distinct species.

We use an approach similar to the one taken by Soltis $\&$ al. (2007) to examine species boundaries between cytotypes of Solidago simplex and compare those results to patterns found in several other polyploid complexes in Solidago (data summarized in Tables 4-5). We adopt de Queiroz's $(1998,2007)$ unified concept that considers species to be segments of separately evolving metapopulation lineages that can be separated by a variety of operational species criteria. We apply four generalized species criteria to cytotypic variation in $S$. simplex. Biological: does gene flow or interbreeding occur between cytotypes? Evolutionary/ecological: do cytotypes represent lineages with differing distributions/ecologies and evolutionary fates? Phylogenetic: do cytotypes represent monophyletic lineages united by shared, derived characters? Taxonomic/phenetic: do cytotypes form morphologically separable clusters of individuals?

- Biological. - Polyploidization has often been cited as a prime example of how sympatric speciation can occur because it confers instantaneous reproductive isolation between the diploid parent and polyploid derivative. This appears to be the case in Solidago simplex. Pollination studies in S. simplex and other goldenrod species indicate that there is strong triploid block in the genus and that interploidy crosses are overwhelmingly (almost entirely) unsuccessful (e.g., Melville \& Morton, 1982; Ringius, 1986). The extensive body of traditional cytological work in the genus also suggests that there are strong intrinsic barriers to intercytotype gene flow and that the formation and establishment of odd ploidy individuals (i.e., triploid or 
pentaploid) are extremely rare events. Semple (1992) found that only $0.12 \%$ ( 8 of 6908 records) of North American chromosome counts for asters and goldenrods were from odd ploidy individuals. Recent cytogeographic studies utilizing flow cytometry (with substantially larger sample sizes than traditional studies) have reached the same conclusion (Halverson \& al., 2008; Schlaepfer \& al., 2008a), suggesting that there is no major triploid or pentaploid bridge between cytotypes. This contrasts with some other species where significantly higher levels of odd-ploidy individuals have been reported within populations (e.g., Galax urceolata, Burton \& Husband, 1999). Halverson $\&$ al.'s (2008) work on S. altissima suggested, however, that gene flow between diploid and hexaploid cytotypes may be facilitated by tetraploid plants where the cytotypes co-occur. It is unclear if this pattern will turn out to be common in other goldenrods that exhibit apparently high levels of cytotype cooccurrence (e.g., in S. curtisii; Cook \& Semple, 2008).

- Evolutionary/ecological. - Ecological differentiation and/or geographic separation of polyploid plants from their diploid relatives have been reported for many species (e.g., $G a$ lax urcoleata, Johnson \& al., 2003; Tolmiea, Judd \& al., 2007), and recent work on polyploidy in Achillea borealis has for the first time demonstrated that polyploidy itself can mediate ecological divergence among cytotypes through changes in fitness (Ramsey, 2011). Cytotypes within $S$. simplex display strong geographic structuring with the diploid cytotype widespread in western North America and the tetraploid cytotype confined to eastern North America. Ringius \& Semple (1987) pointed out that the geographic segregation of cytotypes in $S$. simplex mirrored patterns in other Solidago species, and the data summarized in Table 5 indicate that infraspecific cytotypes in five of the other species show some degree of geographic separation. Interestingly, the pattern in $S$. gigantea and $S$. nemoralis is the opposite of the pattern in $S$. simplex; in those species the polyploid cytotypes have western distributions (Brammall \& Semple, 1990; Schlaepfer \& al., 2008a).

In the Great Lakes region, the main area where both cytotypes of $S$. simplex occur, they show nearly complete ecogeographic separation (Fig. 3). This type of regional ecogeographic segregation is evident within some Solidago species but apparently absent in others (e.g., S. altissima in Halverson \& al., 2008). Tetraploid populations of $S$. uliginosa in the Great Lakes region, while not widely geographically segregated from diploids, occupy a distinct habitat type. Chmielewski \& al. (1987) found that tetraploid $S$. uliginosa was restricted to alvar (limestone pavement) habitats, while diploids were apparently absent from this habitat. Laureto \& Pringle (2010) recently described the octoploid Solidago vossii J.S. Pringle \& P.J. Laureto as a distinct species. This narrow polyploid endemic is restricted to inland, mesic sand prairies in a $6 \mathrm{~km}^{2}$ area of northern Michigan. Its presumed hexaploid progenitor, the U.S. federally threatened S. houghtonii A. Gray, is restricted almost entirely to calcareous Great Lakes shorelines in northern Michigan and Ontario.

- Phylogenetic. - While higher ploidies may superficially seem to be diagnosable by chromosome number (sensu Cracraft, 1983), the apparent frequency of recurrent polyploidization in plants suggests that little phylogenetic weight can be placed

Table 4. Species criteria applied to variation in Solidago simplex.

\begin{tabular}{lllll}
\hline & \multicolumn{4}{c}{ Species criteria } \\
\cline { 2 - 5 } Taxon & Biological & Evolutionary/ecological & Phylogenetic & Phenetic/taxonomic \\
\hline Between & Yes, interploidy crosses & Yes, appear to be distinct & No, morphological variation & Yes, diploids typically \\
subsp. randii & unsuccessful; $3 n$ and $5 n$ & lineages, largely distinct & and cpDNA suggest mul- & have smaller capitula and \\
and & individuals not reported; & geographic ranges, eco- & tiple origins of polyploid & pollen grains, shorter disk \\
subsp. simplex & phenological separation & logical separation in regions & subspecies & corolla lobes, less pubescent \\
& between cytotypes in the & where cytotypes co-occur & & achenes, and less acute leaf \\
& Great Lakes region & & & apices; but sometimes dif- \\
& & & & ficult to distinguish
\end{tabular}

Within $4 n \quad$ Yes (in part), infra-subsubsp. randii species crosses involving var. gillmanii are largely unsuccessful; phenological separation between var. gillmanii and var. ontarioensis in the Great Lakes region

Within $2 n \quad$ Unknown subsp. simplex
Yes, appear to be distinct lineages, largely distinct geographic ranges, ecological separation in regions of co-occurrence; but vars. monticola, ontarioensis, and racemosa all occupy rock substrate habitats

Yes, var. chlorolepis disjunct to eastern Quebec and restricted to serpentine soils; but possible recurrent ecotypic formation of var. nana on different mountain summits
No, morphological variation and cpDNA suggest multiple origins of polyploid varieties; likely more than four distinct lineages present

Unclear, cpDNA does not resolve relationships; vars. chlorolepis and nana not sampled
Yes (in part), var. gillmanii distinct from rest; other varieties differ in leaf shape and margin serration, but all three polymorphic and sometimes difficult to distinguish
Yes (in part), varieties differ in leaf shape, leaf apex shape, and disk corolla lobe length; but vars. chlorolepis and simplex difficult to distinguish

Data were summarized from the following: Ringius (1986), Ringius \& Semple (1987), Semple \& Cook (2006), and Peirson (2010). 
on ploidy alone (Soltis \& Soltis, 1999; Soltis \& al., 2004). As Soltis \& al. (2007) pointed out, this likely recurrent formation is one of the main arguments against recognizing infraspecific polyploids as distinct species. Phylogeographic cpDNA data support a possible recurrent evolution of polyploids in S. simplex (Peirson, in prep.), and this is consistent with general conclusions from some other studied goldenrod species as well (Halverson \& al., 2008; Schlaepfer \& al., 2008b). Laureto \& Barkman (2011) hypothesized a single origin of the hexaploid $S$. houghtonii, but their data also revealed three phylogeographic clusters that could alternatively be interpreted as three independent origins. Robust phylogenetic data is lacking for Solidago (see discussion in Beck \& al., 2004), but recurrent formation of polyploid cytotypes seems likely in a number of species (e.g., S. curtisii and $S$. nemoralis). It is unclear what effects recurrent formation has had on intercytotype gene flow and/or lineage divergence, and additional molecular phylogenetic and population genetic studies will be needed to test these hypotheses.

- Phenetic/taxonomic. - A review by Rieseberg \& Willis (2007) demonstrated that diagnosable phenotypic clusters in plants corresponded to reproductively isolated sets of populations approximately $75 \%$ of the time; thus phenetic gaps between cytotypes should in theory often correlate with reductions in gene flow and at least partial speciation. The subspecies of Solidago simplex are phenetically separable and differ from each other by not only quantitative, ploidy-related morphological traits such as capitula size, phyllary length, and pollen grain diameter but also by leaf and pubescence characters (Table 4). Interestingly though, presumed incipient $S$. simplex tetraploids in otherwise diploid populations are cryptic with their diploid progenitors (Peirson, pers. obs.). Infraspecific cytotypes in some other studied Solidago species are separable by a mix of presumably ploidy-related and non-ploidyrelated traits (Table 5). The pattern in S. nemoralis is similar to the pattern in $S$. simplex. Diploid and tetraploid subspecies differ in capitula, floral, and achene characters, but apparent incipient tetraploids in the otherwise diploid $S$. nemoralis subsp. nemoralis differ from their progenitors only in their slightly larger capitula. Infraspecific cytotypes in several species (e.g., S. curtissii and S. gigantea) are apparently essentially indistinguishable from each other (Melville \& Morton, 1982; Cook \& Semple, 2008; Schlaepfer \& al., 2008a).

Table 5. Species criteria applied to patterns of cytotype variation in six species of Solidago.

\begin{tabular}{|c|c|c|c|c|}
\hline \multirow[t]{2}{*}{ Species } & \multicolumn{4}{|c|}{ Species criteria } \\
\hline & Biological & Evolutionary/ecological & Phylogenetic & Phenetic/taxonomic \\
\hline $\begin{array}{l}\text { Solidago } \\
\text { altissima }\end{array}$ & $\begin{array}{l}\text { Yes, interploidy crosses } \\
\text { unsuccessful; } 3 n \text { and } 5 n \text { in- } \\
\text { dividuals rare, but } 4 n \text { plants } \\
\text { may form a bridge between } \\
2 n \text { and } 6 n \text { cytotypes in } \\
\text { sympatry }\end{array}$ & $\begin{array}{l}\text { Yes, distinct lineages with } \\
\text { distinct geographic ranges } \\
\text { at continental scale, but } \\
\text { local co-occurrence where } \\
\text { cytotype ranges overlap }\end{array}$ & $\begin{array}{l}\text { Yes (in part), } 2 n \text { and } 6 n \\
\text { cytotypes are distinct lin- } \\
\text { eages, but mixed-population } \\
\text { cytotypes are more closely } \\
\text { related to each other (e.g., } \\
\text { lineage recombination?) }\end{array}$ & $\begin{array}{l}\text { Yes (in part), capitula size } \\
\text { differs between } 2 n \text { and } 6 n \\
\text { cytotypes; tetraploids in zone } \\
\text { of sympatry obscure pattern }\end{array}$ \\
\hline $\begin{array}{l}\text { Solidago } \\
\text { curtisii }\end{array}$ & $\begin{array}{l}\text { Unknown, extensive recur- } \\
\text { rent polyploidy may act as } \\
\text { a bridge between cytotypes }\end{array}$ & $\begin{array}{l}\text { No, within population varia- } \\
\text { tion, overlapping ranges, } \\
\text { probable recurrent origins } \\
\text { of polyploids }\end{array}$ & Unknown & $\begin{array}{l}\text { No, cytotypes apparently not } \\
\text { distinguishable }\end{array}$ \\
\hline $\begin{array}{l}\text { Solidago } \\
\text { flexicaulis }\end{array}$ & $\begin{array}{l}\text { Yes, } 3 n \text { individuals very } \\
\text { rare }\end{array}$ & $\begin{array}{l}\text { Yes, distinct lineages with } \\
\text { distinct geographic ranges }\end{array}$ & Unknown & $\begin{array}{l}\text { Yes, capitula size differs be- } \\
\text { tween } 2 n \text { and } 4 n \text { cytotypes }\end{array}$ \\
\hline $\begin{array}{l}\text { Solidago } \\
\text { gigantea }\end{array}$ & $\begin{array}{l}\text { Yes, interploidy crosses } \\
\text { unsuccessful; } 3 n \text { and } 5 n \\
\text { individuals rare }\end{array}$ & $\begin{array}{l}\text { Yes, appear to be distinct } \\
\text { lineages, largely distinct } \\
\text { geographic ranges }\end{array}$ & $\begin{array}{l}\text { No, cpDNA suggests mul- } \\
\text { tiple origins of polyploids }\end{array}$ & $\begin{array}{l}\text { No, cytotypes apparently not } \\
\text { distinguishable }\end{array}$ \\
\hline $\begin{array}{l}\text { Solidago } \\
\text { nemoralis }\end{array}$ & $\begin{array}{l}\text { Yes, } 3 n \text { individuals not } \\
\text { reported }\end{array}$ & $\begin{array}{l}\text { Yes, } 2 n \text { and } 4 n \text { subspecies } \\
\text { are distinct lineages with } \\
\text { distinct geographic ranges, } \\
\text { but sporadic formation of } \\
4 n \text { plants within } 2 n \text { subspe- } \\
\text { cies }\end{array}$ & $\begin{array}{l}\text { Unknown, but presumably } \\
\text { recurrent formation of } 4 n \\
\text { plants within primarily } 2 n \\
\text { subsp. nemoralis }\end{array}$ & $\begin{array}{l}\text { Yes, capitula, floral, and } \\
\text { achene characters differ } \\
\text { between } 2 n \text { and } 4 n \text { subspe- } \\
\text { cies; but cytotypes within } \\
\text { subsp. nemoralis not readily } \\
\text { distinguishable }\end{array}$ \\
\hline $\begin{array}{l}\text { Solidago } \\
\text { rigida }\end{array}$ & $\begin{array}{l}\text { Yes, } 3 n \text { individuals not } \\
\text { reported }\end{array}$ & $\begin{array}{l}\text { Yes, distinct lineages with } \\
\text { largely distinct geographic } \\
\text { ranges }\end{array}$ & Unknown & $\begin{array}{l}\text { Yes, vegetative and phyllary } \\
\text { characters differ between } \\
\text { cytotypes, but sometimes } \\
\text { difficult to distinguish }\end{array}$ \\
\hline
\end{tabular}

In addition to Semple \& Cook (2006), data were summarized from the following: S. altissima (Melville \& Morton, 1982; Halverson \& al., 2008), S. curtissii (Cook \& Semple, 2008; Cook \& al., 2009), S. flexicaulis (Chmielewski \& Semple, 1985; Cook \& Semple, 2008; Cook \& al., 2009), S. gigantea (Melville \& Morton, 1982; Schlaepfer \& al., 2008a, b), S. nemoralis (Brammall \& Semple, 1990; Semple \& al., 1990), and S. rigida (Heard \& Semple, 1988). 


\section{- CONCLUSION}

This study of Solidago simplex and cumulative cytological data from studies of other Solidago species strongly support the idea that polyploidy has been an important factor in the diversification of the genus and that infraspecific chromosomal races in a number of well-studied species represent divergent, reproductively isolated lineages. Soltis \& al. (2007) surmised that the predominant use of traditional morphological species concepts, the practicability (or lack thereof) of describing often cryptic polyploid species, and longstanding botanical tradition have all contributed to the hesitancy of many systematists to recognize infraspecific cytotypes as distinct species. This seems to be the case in $S$. simplex as well. From the species criteria used above, however, there appear to be few biological reasons for recognizing the entities that comprise $S$. simplex subsp. simplex and $S$. simplex subsp. randii as one single species (Table 4). Cytotypes in S. simplex likely cannot interbreed because of intrinsic barriers to intercytotype gene flow (biological species), have almost completely separate geographic ranges and occupy different habitats where they co-occur regionally (ecological/evolutionary species), and are phenetically separable not only by ploidy-related morphological traits like capitula size and phyllary length but also by leaf shape and pubescence characters (phenetic/taxonomic species).

At the same time, however, the case of Solidago simplex also highlights some of the difficulties in trying to parse taxonomically complicated polyploid complexes. As currently circumscribed, polyploid $S$. simplex subsp. randii comprises four varieties. Phylogeographic data suggest that the subspecies may be an assemblage of independently derived polyploid lineages (Peirson, in prep.). A significant part of the taxonomic difficulty then centers on determining which and how many polyploid species to recognize. From a morphological and ecological perspective, S. simplex var. gillmanii clearly warrants recognition as a distinct species (the correct name would be S. gillmanii (A. Gray) E.S. Steele). The species is adapted to active shoreline dune systems in the Great Lakes region and is strikingly distinct from the other polyploid entities in S. simplex. It possesses elongate vertical rhizomes that facilitate survival from sand burial; the Pacific coastal endemic Solidago spathulata is the only other member of $S$. subsect. Humiles that is similarly adapted to active sand dunes. But even with its distinct morphology, is it possible that tetraploid S. gillmanii itself had multiple, independent origins? And if so, have the common selective regime of the sand dune environment and the connectivity of dune systems along the shores of Lakes Huron and Michigan been strong enough forces to shape an assemblage of independent lineages into a single, well-defined species? The apparent convergent evolution of other sand dune endemic goldenrods in the Great Lakes region certainly suggests that dune systems in the region exert strong selective pressures. These and other questions regarding the evolution of $S$. gillmanii remain to be tested.

The three other polyploid varieties of Solidago simplex subsp. randii present greater taxonomic challenges. They are ecogeographically separated and differ slightly in leaf shape and leaf margin serration, but they are all phenotypically variable and lack striking adaptations like those found in var. gillmanii. From an evolutionary standpoint, they are equally as complicated. Not only does phylogeographic data suggest multiple origins, but common garden and morphological data also suggest that $S$. simplex var. ontarioensis and var. racemosa each comprise at least two allopatric, morphologically distinct lineages (Peirson, 2010; Ringius, 1986). In fact, Ringius referred to $S$. simplex var. racemosa as a "complex assemblage of morphotypes", and Greene (1898) recognized the southern populations as the distinct $S$. racemosa. How then should these remaining three polyploid varieties be treated?

All of the available evidence indicates that they should not be subsumed into a broadly defined Solidago simplex, but until additional data is gathered and the evolutionary history of this complex more thoroughly resolved, taxonomic decisions will remain preliminary hypotheses. Recent advances in next-generation sequencing that have facilitated the gathering of genomic-level genetic data for non-model organisms hold significant promise for systems like this (Hudson, 2008; Emerson \& al., 2010). An approach similar to the one used by Griffin $\&$ al. (2011) to examine the evolution of polyploid Australian alpine grasses will be essential to untangling the complicated evolution of polyploidy in Solidago simplex and other polyploid complexes in Solidago. While a complete picture of the evolution of polyploidy in Solidago is for now still out of reach, it is clear that effective biological species diversity in the genus is considerably higher than currently recognized taxonomically.

\section{ACKNOWLEDGEMENTS}

We thank P. Kron and B. Husband (University of Guelph) for invaluable assistance with the flow cytometry and G. Nesom (Botanical Research Institute of Texas) for providing an unpublished chromosome count for $S$. plumosa. We thank two anonymous reviewers for their critical evaluations of the manuscript. Funds for this project were provided by grants to J. Peirson from the National Science Foundation (Doctoral Dissertation Improvement Grant), Hanes Memorial Fund, Michigan Botanical Foundation, and the University of Michigan and by Discovery Grants to J. Semple from the Natural Sciences and Engineering Research Council of Canada.

\section{口 LITERATURE CITED}

Artyukova, E.V., Kozyrenko, M.M., Kholina, A.B. \& Zhuravlev, Y.N. 2011. High chloroplast haplotype diversity in the endemic legume Oxytropis chankaensis may result from independent polyploidization events. Genetica 139: 221-232.

Beaudry, J.R. 1963. Studies on Solidago L. VI: Additional chromosome numbers of taxa of the genus Solidago. Canad. J. Genet. Cytol. 5: 150-174.

Beaudry, J.R. 1969. Études sur les Solidago L. IX: Une troisième liste de nombres chromosomiques des taxons du genre Solidago et de certains genres voisins. Naturaliste Canad. 96: 103-122.

Beaudry, J.R. \& Chabot, D.L. 1959. Studies on Solidago L. IV. The chromosome numbers of certain taxa of the genus Solidago. $\mathrm{Ca}$ nad. J. Bot. 37: 209-228. 
Beck, J.B., Nesom, G.L., Calie, P.J., Baird, G.I., Small, R.L. \& Schilling, E.E. 2004. Is subtribe Solidagininae (Asteraceae) monophyletic? Taxon 53: 691-698.

Brammall, R.A. \& Semple, J.C. 1990. The cytotaxonomy of Solidago nemoralis (Compositae: Astereae). Canad. J. Bot. 68: 2065-2069.

Brochmann, C., Brysting, A.K., Alsos, I.G., Borgen, L., Grundt, H.H., Scheen, A.C. \& Elven, R. 2004. Polyploidy in arctic plants. Biol. J. Linn. Soc. 82: 521-536.

Brouillet, L., Semple, J.C., Allen, G.A., Chambers, K.L. \& Sundberg, S.D. 2006. Symphyotrichum. Pp. 465-539 in: Flora of North America Editorial Committee (ed.), Flora of North America, vol. 20. New York: Oxford University Press.

Burton, T.L. \& Husband, B.C. 1999. Population cytotype structure in the polyploid Galax urceolata (Diapensiaceae). Heredity 82: 381-390.

Chmielewski, J.G. \& Semple, J.C. 1985. The cytogeography and post-glacial migration of Solidago flexicaulis (Compositae) into southern Ontario. Naturaliste Canad. 112: 307-311.

Chmielewski, J.G., Ringius, G.S. \& Semple, J.C. 1987. The cytogeography of Solidago uliginosa (Compositae, Astereae) in the Great Lakes region. Canad. J. Bot. 65: 1045-1046.

Clausen, J., Keck, D.D. \& Hiesey, W.M. 1945. Experimental studies on the nature of species. 2. Plant evolution through amphiploidy and autoploidy, with examples from Madiinae. Publ. Carnegie Inst. Washington 564: 1-174.

Cook, R.E. \& Semple, J.C. 2008. Cytogeography of Solidago subsect. Glomeruliflorae (Asteraceae: Astereae). Botany 86: 1488-1496.

Cook, R.E., Semple, J.C. \& Baum, B.R. 2009. A multivariate morphometric analysis of Solidago subsect. Glomeruliflorae (Asteraceae: Astereae). Botany 87: 97-111.

Coyne, J.A. \& Orr, H.A. 2004. Speciation. Sunderland, Massachusetts: Sinauer.

Cracraft, C. 1983. Species concepts and speciation analysis. Ornithology 1: 159-187.

De Queiroz, K. 1998. The general lineage concept of species, species criteria, and the process of speciation. Pp. 57-75 in: Howard, D.J. \& Berlocher, S.H. (eds.), Endless forms. New York: Oxford University Press.

De Queiroz, K. 2007. Species concepts and species delimitation. Syst. Biol. 56: 879-886.

Dolezel, J., Binarová, P. \& Lucretti, S. 1989. Analysis of nuclear DNA in plant cells by flow cytometry. Biol. Pl. 31: 113-120.

Dolezel, J., Dolezelova, M. \& Novak, F.J. 1994. Flow cytometric estimation of nuclear DNA amount in diploid bananas (Musa acuminata and M. balbisiana). Biol. Pl. 36: 351-357.

Dolezel, J., Greilhuber, J. \& Suda, J. 2007. Estimation of nuclear DNA content in plants using flow cytometry. Nature Protocols 2: 2233-2244

Ehrendorfer, F. 1980. Polyploidy and distribution. Pp. 45-60 in: Lewis, W.H. (ed.), Polyploidy: Biological relevance. New York: Plenum Press.

Emerson, K.J., Merz, C.R., Catchen, J.M., Hohenlohe, P.A., Cresko, W.A., Bradshaw, W.E. \& Holzapfel, C.M. 2010. Resolving postglacial phylogeography using high-throughput sequencing. Proc. Nat. Acad. Sci. U.S.A. 107: 16196-16200.

Gervais, C., Trahan, R. \& Gagnon, J. 1999. IOPB Chromosome Data 14. Newslett. Int. Organ. Pl. Biosyst. 30: 10-11.

Grant, V. 1981. Plant speciation, 2nd ed. New York: Columbia University Press.

Greene, E.L. 1898. Studies in the Compositae-VII. Pittonia 3: 264-298.

Griffin, P.C., Robin, C. \& Hoffmann, A.A. 2011. A next-generation sequencing method for overcoming the multiple gene copy problem in polyploid phylogenetics, applied to Poa grasses. B. M. C. Biol. 9: 19. DOI: 10.1186/1741-7007-9-19.

Halverson, K., Heard, S.B., Nason, J.D. \& Stireman, J.O. 2008. Origins, distribution, and local co-occurrence of polyploid cytotypes in Solidago altissima (Asteraceae). Amer. J. Bot. 95: 50-58.
Hartman, R.L. 1977. Pp. 270-271 in: Löve, A. (ed.), IOPB chromosome number reports LVI. Taxon 26: 257-274.

Haskell, G. 1951. Plant chromosome races and their ecology in Great Britain. Nature 167: 628-629.

Heard, S.B. \& Semple, J.C. 1988. The Solidago rigida complex (Compositae: Astereae): A multivariate morphometric analysis and chromosome numbers. Canad. J. Bot. 66: 1800-1807.

Hiddeman, W., Schumann, J., Andreef, M., Barlogie, B., Herman, C.J., Leif, R.C., Mayall, B.H., Murphy, R.F. \& Sandberg, A.A. 1984. Convention on nomenclature for DNA cytometry. Cytometry 5: 445-446.

Hudson, M.E. 2008. Sequencing breakthroughs for genomic ecology and evolutionary biology. Molec. Ecol. Resources 8: 3-17.

Johnson, M.T., Husband, B.C. \& Burton, T.L. 2003. Habitat differentiation between diploid and tetraploid Galax urceolata (Diapensiaceae). Int. J. Pl. Sci. 164: 703-710.

Johnston, A. 1958. Note on the distribution of rough fescue (Festuca scabrella Torr.). Ecology 39: 536.

Judd, W.S., Soltis, D.E., Soltis, P.S. \& Ionta, G. 2007. Tolmiea diplomenziesii: A new species from the Pacific Northwest and the diploid sister taxon of the autotetraploid T. menziesii (Saxifragaceae). Brittonia 59: 217-225.

Keener, B.R. \& Kral, R. 2003. A new species of Solidago (Asteraceae: Astereae) from north central Alabama. Sida 20: 1589-1593.

Keil, D.J. \& Pinkava, D.J. 1979. Pp. 271-273 in: Löve, A. (ed.), IOPB chromosome number reports LIX. Taxon 28: 265-279.

Laureto, P.J. \& Barkman, T.J. 2011. Nuclear and chloroplast DNA suggest a complex single origin for the threatened allopolyploid Solidago houghtonii (Asteraceae) involving reticulate evolution and introgression. Syst. Bot. 36: 209-226.

Laureto, P.J. \& Pringle, J.S. 2010. Solidago vossii (Asteraceae), a new species of goldenrod from northern Michigan. Michigan Botanist 49: $105-117$

Lewis, W.H. 1980. Polyploidy in species populations. Pp. 103-144 in: Lewis, W.H. (ed.), Polyploidy: Biological relevance. New York: Plenum Press.

Löve, A. \& Löve, D. 1943. The significance of differences in the distribution of diploids and polyploids. Hereditas (Lund) 29: 145-163.

Löve, A., Löve, D. \& Kapoor, B.M. 1971. Cytotaxonomy of a century of Rocky Mountain orophytes. Arctic Alpine Res. 3: 139-165.

Masterson, J. 1994. Stomatal size in fossil plants: Evidence for polyploidy in the majority of angiosperms. Science 264: 421-424.

Melville, M.R. \& Morton, J.K. 1982. A biosystematic study of the Solidago canadensis (Compositae) complex. I. The Ontario populations. Canad. J. Bot. 60: 976-997.

Morton, J.K. 1981. Chromosome numbers in Compositae from Canada and the U.S.A. Bot. J. Linn. Soc. 82: 357-368.

Mulligan, G.A., Cody, W.J. \& Grainger, N. 1972. Pp. 498-499 in: Löve, A. (ed.), IOPB chromosome number reports XXXVII. Taxon 21: 495-500.

Muntzing, A. 1936. The evolutionary significance of autopolyploidy. Hereditas (Lund) 21: 263-378.

Mustard, T.S. 1982. The distribution and autecology of pale agoseris, Agoseris glauca, in Michigan. Michigan Botanist 21: 205-211.

Otto, S.P. \& Whitton, J. 2000. Polyploid incidence and evolution. Annual Rev. Genet. 34: 401-437.

Parisod, C., Holderegger, R. \& Brochmann, C. 2010. Evolutionary consequences of autopolyploidy. New Phytol. 186: 5-17.

Peirson, J.A. 2010. Biogeography, ecology, and evolution of the endemic vascular flora of the glaciated Great Lakes region: A case study of the Solidago simplex species complex. Doctoral Dissertation, The University of Michigan, Ann Arbor, Michigan, U.S.A.

Ramsey, J. 2011. Polyploidy and ecological adaptation in wild yarrow. Proc. Natl. Acad. Sci. U.S.A. 108: 7096-7101.

Raven, P.H., Solbrig, O.T., Kyhos, D.W. \& Snow, R. 1960. Chromosome numbers in Compositae I: Astereae. Amer. J. Bot. 47: 124-132. 
Rebernig, C.A., Weiss-Schneeweiss, H., Schneeweiss, G.M., Schönswetter, P., Obermayer, R., Villaseñor, J.L. \& Stuessy, T.F. 2010. Quaternary range dynamics and polyploid evolution in an arid brushland plant species (Melampodium cinereum, Asteraceae). Molec. Phylogenet. Evol. 54: 594-606.

Rieseberg, L.H. \& Willis, J.H. 2007. Plant speciation. Science 317: 910-914.

Ringius, G.S. 1986. A biosystematic study of the Solidago spathulata DC.-S. glutinosa Nutt. complex (Compositae: Astereae). Doctoral Dissertation, University of Waterloo, Waterloo, Canada.

Ringius, G.S. \& Semple, J.C. 1987. Cytogeography of the Solidago spathulata-glutinosa complex (Compositae, Astereae). Canad. J. Bot. 65: 2458-2462.

Schlaepfer, D.R., Edwards, P.J., Semple, J.C. \& Billeter, R. 2008a. Cytogeography of Solidago gigantea (Asteraceae) and its invasive ploidy level. J. Biogeogr. 35: 2119-2127.

Schlaepfer, D.R., Edwards, P.J., Widmer, A. \& Billeter, R. 2008 b. Phylogeography of native ploidy levels and invasive tetraploids of Solidago gigantea. Molec. Ecol. 17: 5245-5256.

Segraves, K.A., Thompson, J.N., Soltis, P.S. \& Soltis, D.E. 1999. Multiple origins of polyploidy and the geographic structure of Heuchera grossulariifolia. Molec. Ecol. 8: 253-262.

Semple, J.C. 1992. A geographic summary of chromosome number reports for North American asters and goldenrods (Asteraceae: Astereae). Ann. Missouri Bot. Gard. 79: 95-109.

Semple, J.C. 2003. New names and combinations in goldenrods, Solidago (Asteraceae: Astereae). Sida 20: 1605-1616.

Semple, J.C. \& Cook, R.E. 2004. Chromosome number determinations in fam. Compositae, tribe Astereae VII: Mostly eastern North American and some Eurasian taxa. Rhodora 106: 253-272.

Semple, J.C. \& Cook, R.E. 2006. Solidago. Pp. 107-166 in: Flora of North America Editorial Committee (ed.), Flora of North America, vol. 20. New York: Oxford University Press.

Semple, J.C. \& Watanabe, K. 2009. A review of chromosome numbers in the Asteraceae with hypotheses on chromosomal base number evolution. Pp. 61-72 in: Funk, V.A., Susanna, A., Stuessy, T.F. \& Bayer, R.J. (eds.), Systematics, evolution, and biogeography of Compositae. Vienna: International Association for Plant Taxonomy.

Semple, J.C., Brammall, R.A. \& Chmielewski, J. 1981. Chromosome numbers of goldenrods, Euthamia and Solidago (CompositaeAstereae). Canad. J. Bot. 59: 1167-1173.

Semple, J.C., Chmielewski, J.G. \& Brammall, R.A. 1990. A multivariate morphometric study of Solidago nemoralis (Compositae: Astereae) and comparison with S. californica and S. sparsiflora. Canad. J. Bot. 68: 2070-2082.

Semple, J.C., Chmielewski, J.G. \& Lane, M.A. 1989. Chromosome number determinations in fam. Compositae, tribe Astereae III: Additional counts and comments on generic limits and ancestral base numbers. Rhodora 91: 296-314.

Semple, J.C., Chmielewski, J.G. \& Xiang, C. 1992. Chromosome number determinations in fam. Compositae, tribe Astereae IV: additional reports and comments on the cytogeography and status of some species of Aster and Solidago. Rhodora 94: 48-62.
Semple, J.C., Xiang, C., Zhang, J., Horsburgh, M. \& Cook, R. 2001. Chromosome number determinations in fam. Compositae, tribe Astereae VI: Western North American taxa and comments on generic treatments of North American asters. Rhodora 103: 202-218.

Severns, P.M. \& Liston, A. 2008. Intraspecific chromosome number variation: A neglected threat to the conservation of rare species. Conservation Biol. 22: 1641-1647.

Soltis, D.E. \& Soltis, P.S. 1999. Polyploidy: Recurrent formation and genome evolution. Trends Ecol. Evol. 14: 348-352.

Soltis, D.E., Albert, V.A., Leebens-Mack, J., Bell, C.D., Paterson, A.H., Zheng, C., Sankoff, D., dePamphilis, C.W., Wall, P.K. \& Soltis, P.S. 2009. Polyploidy and angiosperm diversification. Amer. J. Bot. 96: 336-348.

Soltis, D.E., Buggs, R.J.A., Doyle, J.J. \& Soltis, P.S. 2010. What we still don't know about polyploidy. Taxon 59: 1387-1403.

Soltis, D.E., Soltis, P.S., Schemske, D.W., Hancock, J.F., Thompson, J.N., Husband, B.C. \& Judd, W.S. 2007. Autopolyploidy in angiosperms: Have we grossly underestimated the number of species? Taxon 56: 13-30.

Soltis, D.E., Soltis, P.S. \& Tate, J.A. 2004. Advances in the study of polyploidy since Plant Speciation. New Phytol. 161: 173-191.

Soltis, P.S. \& Soltis, D.E. 2000. The role of genetic and genomic attributes in the success of polyploids. Proc. Natl. Acad. Sci. U.S.A. 97: 7051-7057.

Stebbins, G.L. 1942. Polyploid complexes in relation to ecology and the history of floras. Amer. Naturalist 76: 36-45.

Stebbins, G.L. 1950. Variation and evolution in plants. New York: Columbia University Press.

Stebbins, G.L. 1971. Chromosomal evolution in Higher Plants. Reading: Addison-Wesley.

Symonds, V.V., Soltis, P.S. \& Soltis, D.E. 2010. Dynamics of polyploid formation in Tragopogon (Asteraceae): Recurrent formation, gene flow, and population structure. Evolution 64: 1984-2003.

Taylor, R.L. \& Taylor, S. 1977. Chromosome numbers of vascular plants of British Columbia. Syesis 10: 125-138.

Trock, D.K. 2006. Packera. Pp. 570-602 in: Flora of North America Editorial Committee (ed.), Flora of North America, vol. 20. New York: Oxford University Press.

Voss, E.G. 1996. Michigan flora, pt. 3, Dicots (Pyrolaceae - Compositae). Bulletin of the Cranbrook Institute of Science 61. Bloomfield Hills, Michigan: Cranbrook Institute of Science.

Ward, D.E. \& Spellenberg, R.W. 1986. Chromosome counts of angiosperms of western North America. Phytologia 61: 119-125.

Wendel, J.F. 2000. Genome evolution in polyploids. Pl. Molec. Biol. 42: 225-249.

Wood, T.E., Takebayashi, N., Barker, M.S., Mayrose, I., Greenspoon, P.B. \& Rieseberg, L.H. 2009. The frequency of polyploid speciation in vascular plants. Proc. Natl. Acad. Sci. U.S.A. 106: 1387513879.

Zimmerman, D.A. 1956. The jack pine association in the Lower Peninsula of Michigan: Its structure and composition, Doctoral Dissertation, University of Michigan, Ann Arbor, Michigan, U.S.A. 